\title{
Evidence for a Functional Role of Endogenously Produced Somatomedinlike Peptides in the Regulation of DNA Synthesis in Cultured Human Fibroblasts and Porcine Smooth Muscle Cells
}

\author{
David R. Clemmons and Judson J. Van Wyk \\ Departments of Medicine, Pediatrics, and Center for Thrombosis and Hemostasis, University of North Carolina School of Medicine,
} Chapel Hill, North Carolina 27514

\begin{abstract}
Cultured porcine aortic smooth muscle cells and human fibroblasts produce somatomedinlike peptides and secrete them into the surrounding microenvironment. This production has been linked to their ability to replicate. The objective of this study was to determine if a specific anti-somatomedin-C (Sm-C) monoclonal antibody that binds the somatomedinlike peptides could inhibit replication by porcine aortic smooth muscle cells and human fibroblasts. To determine if the antibody could inhibit the effect of endogenously produced somatomedinlike peptide, increasing concentrations of antibody were co-incubated with platelet-derived growth factor, a known stimulant of somatomedinlike peptide secretion, and $\mathrm{Sm}-\mathrm{C}$-deficient plateletpoor plasma. Addition of the antibody reduced fibroblast $\left[{ }^{3} \mathrm{H}\right]$ thymidine incorporation from $35,100 \pm 500$ to $10,600 \pm 700$ cpm $(P<0.001)$, and in smooth muscle cells from $29,600 \pm 1,800$ to $10,800 \pm 1,100 \mathrm{cpm}(P<0.001)$. Co-incubation of exogenously added $\mathrm{Sm}-\mathrm{C}(20 \mathrm{ng} / \mathrm{ml})$ with maximally inhibitory dilutions of antibody increased $\left[{ }^{3} \mathrm{H}\right]$ thymidine incorporation in fibroblasts from 7,800 $\pm 1,000$ to $18,900 \pm 800 \mathrm{cpm}(P<0.01)$, and in smooth muscle cells from $9,800 \pm 1,200$ to $17,200 \pm 1,100 \mathrm{cpm}$ $(P<0.01)$. Insulin, which can substitute for $\mathrm{Sm}-\mathrm{C}$ as a mitogen and does not bind to the antibody, stimulated DNA synthesis when co-incubated with the antibody, thereby excluding the possibility of nonspecific cytotoxicity. These results strengthen the hypothesis that the rate of DNA synthesis of these two cell types in vitro is directly linked to their capacity to produce somatomedinlike peptides. They further support the cellular production of somatomedinlike peptides as examples of the autocrine model of growth regulation.
\end{abstract}

\section{Introduction}

Somtomedin-C (Sm-C), ${ }^{1}$ also known as insulin-like growth factor-I, is a peptide growth factor that stimulates the replication of many types of cells both in vitro and in vivo $(1,2)$. Plasma concentrations of $\mathrm{Sm}-\mathrm{C}$ are growth hormone dependent and

Address correspondence to Dr. Clemmons, Department of Medicine.

Received for publication 1 October 1984 and in revised form 26 January 1985.

1. Abbreviations used in this paper: DMEM, Dulbecco's modified Eagle's medium; MEM, minimal essential medium; PDGF, plateletderived growth factor; PPP, platelet-poor plasma; Sm-C, somatomedin-C.

J. Clin. Invest.

(C) The American Society for Clinical Investigation, Inc.

0021-9738/85/06/1914/05 $\$ 1.00$

Volume 75, June 1985, 1914-1918 the administration of growth hormone to either normal individuals or growth hormone-deficient patients results in a prompt rise in plasma Sm-C $(3,4)$. The origin of the form of $\mathrm{Sm}-\mathrm{C}$ that circulates in plasma is not clear. Several investigators have shown that many types of cells in tissue culture produce peptides that cross-react with $\mathrm{Sm}-\mathrm{C}$ in radioimmunoassays and radio-receptor assays (5-7). Partially purified preparations of these somatomedin $(\mathrm{Sm})$ like peptides from conditioned medium have also been shown to be biologically active (8).

In a previous study we observed that after exposure to platelet-derived growth factor (PDGF), human fibroblasts were able to initiate DNA synthesis in media containing Sm-Cdeficient plasma (9). Initiation of DNA synthesis could be prevented, however, if the conditioned media were removed every $2 \mathrm{~h}$ and replaced with fresh media supplemented only with $\mathrm{Sm}-\mathrm{C}$ deficient plasma. The addition of pure $\mathrm{Sm}-\mathrm{C}$ to cultures treated in an identical manner allowed DNA synthesis to occur. Although we interpreted these studies to mean that the replication of human fibroblasts in Sm-C deficient media was dependent on endogenously secreted Sm-like compounds, this interpretation was confounded by the possibility that the media changes removed other secreted products that were necessary for cell division.

Recently, this laboratory and several others have prepared monoclonal antibodies to $\mathrm{Sm}-\mathrm{C}$ that are specific for this peptide $(10-12)$. The antibody designated $\mathrm{Sm} 1.2$ that is currently used in our laboratory has $5 \%$ cross-reactivity with human insulinlike growth Factor II, $1 \%$ cross-reactivity with rat insulinlike growth Factor II, and no binding to insulin at $10^{-6} \mathrm{M}$ (12). Addition of this antibody to Balb/c 3T3 cells (a $\mathrm{Sm}-\mathrm{C}$-dependent cell type) blocks the ability of $\mathrm{Sm}-\mathrm{C}$ to stimulate DNA synthesis (13). Since secretion of Sm-like peptides by cultured human fibroblasts and smooth muscle cells may control their ability to replicate, the present studies were undertaken to determine if immunoneutralization of these Sm-like peptides by a monoclonal antibody could block DNA synthesis.

\section{Methods}

Smooth muscle cells were isolated from the aortas of 3-wk-old piglets by a previously published method (14). Stock cultures were maintained on 10-cm dishes (Falcon 3001, Falcon Labware Div., Becton-Dickinson \& Co., Oxnard, CA) in Dulbecco's modified Eagle's medium (DMEM) supplemented with $10 \%$ fetal calf serum (Gibco Laboratories, Grand Island, NY), $10 \mathrm{mM}$ glutamine (Gibco Laboratories), $100 \mathrm{U} / \mathrm{ml}$ penicillin, and $100 \mu \mathrm{g} / \mathrm{ml}$ streptomycin (Gibco Laboratories). The media were changed every third day until growth was confluent (8-11 d), then the cells were removed by exposure to $0.05 \%$ trypsin, $0.02 \%$ EDTA (Gibco Laboratories), and replated using a passage dilution of $1: 3$.

Human fibroblasts were purchased from the Human Mutant Genetic Cell Repository, Camden, NJ. Strain GM0498 was derived 
from the skin of an apparently normal 3-yr-old donor. Strain AG3204 was derived from the lung of a 16-wk fetus. These cells were transformed with SV-40 virus. They were $10 \%$ t-antigen positive with a low frequency of v-antigen positive cells. Both stock cultures were maintained in minimum essential medium (MEM) (Gibco Laboratories) supplemented with $10 \%$ calf serum (Colorado Serum Co., Denver, CO). Stock cultures were maintained in 10-cm dishes (Falcon 3001, Falcon Labware Div., Becton-Dickinson \& Co.) and passaged at weekly intervals, and cultures between the 7th and 12th passage were used. Experiments designed to determine the rate of DNA synthesis were performed by subculturing each of the cell types in microtest wells (Falcon 3004, Falcon Labware Div., Becton-Dickinson \& Co.) and incubating them for $5 \mathrm{~d}$ after plating (plating density 3,000 cells/well) without a medium change. After this interval, the monolayers were washed three times with PBS and exposed to DMEM (smooth muscle cells) or MEM (fibroblasts) that contained $0.5 \mu \mathrm{Ci}\left[{ }^{3} \mathrm{H}\right]$ thymidine $(10$ $\mathrm{Ci} / \mathrm{mmol}$, Schwartz/Mann Div., Becton-Dickinson Immunodiagnostics, Orangeburg, NY) and the stated concentration of test hormone or growth factor. In some experiments, cells were first exposed to PDGF for $5 \mathrm{~h}$ in serum-free medium and then washed three times and exposed to Sm-C-deficient platelet-poor plasma (PPP) in MEM or DMEM that contained $0.5 \mu \mathrm{Ci}\left[{ }^{3} \mathrm{H}\right]$ thymidine. After $30 \mathrm{~h}$ (smooth muscle) or $36 \mathrm{~h}$ (fibroblast) incubation, the reaction was terminated and $\left[{ }^{3} \mathrm{H}\right]$ thymidine incorporation into TCA insoluble material was determined (15).

To determine growth velocity, aortic smooth muscle cells were plated in $16-\mathrm{mm}$ dishes at a density of $6,000 \mathrm{cells} / \mathrm{cm}^{2}$ in DMEM that contained 3\% Sm-C-deficient PPP. After incubating $16 \mathrm{~h}$ at $37^{\circ} \mathrm{C}$ for attachment, triplicate cultures received $0.75 \mathrm{ml}$ of DMEM that contained the test reagents and the incubation was continued for $72 \mathrm{~h}$. At that time, the cells from triplicate plates were detached with $0.05 \%$ trypsin and $0.02 \%$ EDTA, and cell number was determined by counting in a particle data counter (Coulter model ZBI, Coulter Electronics, Inc., Hialeah, FL). The cell number was determined at 6 and $9 \mathrm{~d}$ of incubation in two additional sets of triplicate cultures that were cultured in media that contained identical test reagents.

Anti-Sm-C monoclonal antibody was prepared by a method previously described (12). The immunoglobulin fraction from a cultured clone of mouse myeloma cells, designated 1.2, was further purified from ascites fluid by sequential precipitation in 18 and $15 \%$ sodium sulfate. The antibody was an IgG, kappa, and bound $\mathrm{Sm}-\mathrm{C}$ with an affinity constant of $1.09 \times 10^{10} \mathrm{liter} / \mathrm{mol}$. A monoclonal antibody to horse apoferritin was prepared by the same method. PDGF (16) was purified by previously described methods; it was estimated to be $\sim 13 \%$ pure and did not cross-react with Sm-C antibody when tested at 800 $\mathrm{ng} / \mathrm{ml}$. The PDGF concentrations used in the experiments are expressed as total protein (17). $\mathrm{Sm}-\mathrm{C}$ was purified by a published method and was pure by multiple criteria (18). Sm-C-deficient PPP was obtained from growth hormone-deficient patients, and prepared as described previously (16). It contained $<10 \mathrm{ng} / \mathrm{ml}$ platelet factor IV and $<2$ $\mathrm{ng} / \mathrm{ml} \mathrm{Sm}-\mathrm{C}$. The Sm-like peptide secreted by human fibroblasts was purified from conditioned media by a previously described method (19). The material was estimated to be $>80 \%$ pure by polyacrylamide gel electrophoresis analysis. Statistical analysis of the data was performed using $t$ test and significance was defined at the $95 \%$ level.

\section{Results}

Human fibroblast DNA synthesis was stimulated from a basal level of $6,300 \pm 1,000$ to $29,800 \pm 700 \mathrm{cpm}(P<0.001)$ in cultures incubated with $10 \%$ human serum and to $35,100 \pm 500$ cpm $(P<0.001)$ when incubated with PDGF and $2 \%$ Sm-Cdeficient PPP (Fig. 1). Co-incubation with increasing concentrations of anti-Sm-C monoclonal antibody $(1 / 10,000-1 / 1,000)$ resulted in a progressive decrease in $\left[{ }^{3} \mathrm{H}\right]$ thymidine incorporation to $10,200 \pm 600 \mathrm{cpm}(P<0.001)$. Incubation of pure $\mathrm{Sm}-\mathrm{C}$ or insulin with an antibody dilution of $1 / 1,000$ resulted

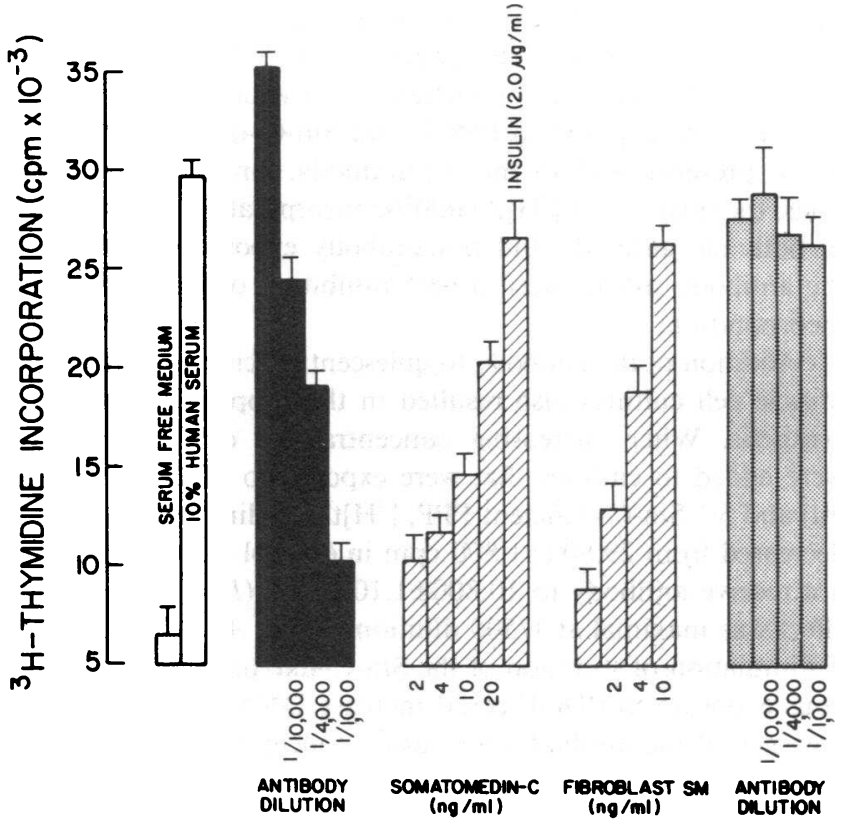

Figure 1. Effect of anti-Sm-C antibody on $\left[{ }^{3} \mathrm{H}\right]$ thymidine incorporation into normal and SV-40-infected human fibroblasts. Fibroblast cultures were plated at a density of 3,000 cells/microtest well and grown to confluent density in MEM supplemented with $10 \%$ calf serum. $4 \mathrm{~d}$ after the last media change the media were aspirated and the cultures washed three times with serum-free MEM. All cultures were exposed to PDGF plus 2\% Sm-C-deficient PPP in an incubation volume of $0.2 \mathrm{ml}$ MEM that contained $0.5 \mu \mathrm{Ci}\left[{ }^{3} \mathrm{H}\right]$ thymidine. Triplicate normal fibroblast $\square$ and $S V-40$-infected cultures $\square$ received increasing concentrations of $\mathrm{Sm} \mathrm{1.2.} \mathrm{Additional} \mathrm{normal} \mathrm{fibroblast}$ cultures received a 1/1,000 dilution of $\mathrm{Sm} 1.2 \mathrm{a}$ and increasing concentrations of $\mathrm{Sm}-\mathrm{C}$, insulin, or fibroblast $\mathrm{Sm}$-like peptide. The results are expressed as the mean \pm 1 SD for triplicate cultures.

in significant increases in $\left[{ }^{3} \mathrm{H}\right]$ thymidine incorporation from $7,800 \pm 900$ to $19,900 \pm 800$ (Sm-C) and $26,400 \pm 1,400$ (insulin) cpm $(P<0.001)$. Addition of a highly purified preparation of the fibroblast Sm-like peptide to cultures that were exposed to antibody (1/1,000 dilution) stimulated DNA synthesis at concentrations between 2 and $10 \mathrm{ng} / \mathrm{ml}$. The increase in DNA synthesis induced by $10 \mathrm{ng} / \mathrm{ml}$ fibroblast $\mathrm{Sm}(25,000 \pm 500$ cpm) was significantly $(P<0.01)$ greater than that stimulated by $20 \mathrm{ng} / \mathrm{ml}$ pure $\mathrm{Sm}-\mathrm{C}$. To determine if the effect of the antibody was specific for fibroblasts that secreted Sm-like peptides, the response of SV-40-transformed human fibroblasts (a cell type which secretes very little $\mathrm{Sm}$ ) to antibody addition was determined. Confluent SV-40-transformed fibroblast cultures released $<0.1 \mathrm{ng} / \mathrm{ml}$ fibroblast $\mathrm{Sm}$ after $24 \mathrm{~h}$ incubation. In addition, exposure of these cultures to pure $\mathrm{Sm}-\mathrm{C}$ resulted in an increase in $\left[{ }^{3} \mathrm{H}\right]$ thymidine incorporation from a baseline of $36,950 \pm 250-37,400 \pm 340 \mathrm{cpm}$. This increase was not significant. When these SV-40-transformed fibroblast cultures were exposed to PDGF plus 2\% Sm-C-deficient PPP and a $1 /$ 1,000 dilution of $\mathrm{Sm} 1.2$ there was no significant change in $\left[{ }^{3} \mathrm{H}\right]$ thymidine incorporation $(28,300 \pm 600-27,200 \pm 800 \mathrm{cpm})$ $(P>0.05)$.

To exclude the possibility that $\left[{ }^{3} \mathrm{H}\right]$ thymidine incorporation was falsely reduced due to differences in the intracellular thymidine pools at the start of the incubation, triplicate cultures were incubated with media that contained $0.5 \mu \mathrm{Ci}$ 
$\left[{ }^{3} \mathrm{H}\right]$ thymidine and an excess of unlabeled thymidine $\left(10^{-6} \mathrm{M}\right)$ plus 2-deoxycytidine triphosphate $\left(5 \times 10^{-5} \mathrm{M}\right)$ to limit inhibition of ribonucleotide reductase by thymidine excess. The cultures were exposed to PDGF and Sm-C-deficient PPP 2\% in the presence and absence of antibody. Under these conditions, the quantity of $\left[{ }^{3} \mathrm{H}\right]$ thymidine incorporation was reduced in both the antibody and nonantibody exposed cultures but the antibody still induced a $68 \%$ inhibition of $\left[{ }^{3} \mathrm{H}\right]$ thymidine incorporation.

Addition of the antibody to quiescent porcine aortic smooth muscle cell cultures also resulted in the suppression of DNA synthesis. When increasing concentrations of the antibody were added to cultures that were exposed to PDGF (200 ng/ $\mathrm{ml}$ ) and 5\% Sm-C-deficient PPP, $\left[{ }^{3} \mathrm{H}\right]$ thymidine incorporation decreased from $29,600 \pm 1,800 \mathrm{cpm}$ in control cultures that did not receive antibody to $10,800 \pm 1,100 \mathrm{cpm}(P<0.001)$. This effect was maximal at $1 / 500$ dilution (Fig. $2 A$ ). To determine if stimulation of secretion of the Sm-C-like peptide by continuous exposure to PDGF could increase DNA synthesis in the presence of the antibody, increasing concentrations of PDGF (a known stimulant of Sm-C-like peptide production) were co-incubated with cultures in the presence of $5 \% \mathrm{Sm}-\mathrm{C}$ deficient PPP plus a 1/5,000 dilution of antibody. At this relatively high antibody dilution, increasing concentrations of PDGF were capable of stimulating DNA synthesis (Fig. $2 \mathrm{~B}$ ). Even at the highest concentration of PDGF, however, the antibody reduced $\left[{ }^{3} \mathrm{H}\right]$ thymidine incorporation from $29,600 \pm 1,800$ to $21,300 \pm 1,500 \mathrm{cpm}(P<0.01)$, which suggested that at least part of the stimulatory effect of PDGF was due to stimulation of secretion of the Sm-like peptide.

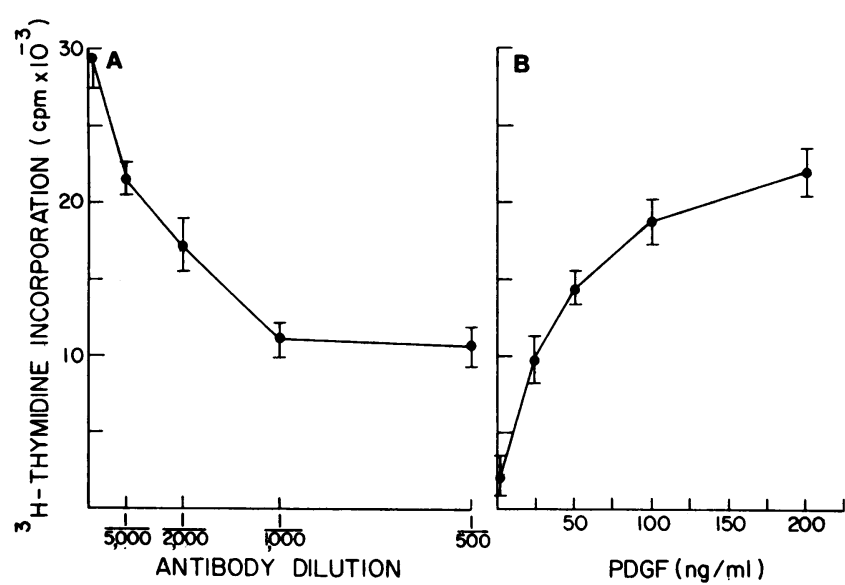

Figure 2. Inhibition of the effect of endogenously secreted Sm-like peptides by the monoclonal antibody. Smooth muscle cells were isolated from young piglet aortas and were subcultured by plating at 3,000 cells/microtest well and grown to high density in DMEM supplemented with $10 \%$ fetal calf serum. $5 \mathrm{~d}$ after plating, triplicate cultures were washed two times with serum-free DMEM then exposed to $0.2 \mathrm{ml}$ DMEM that contained $0.5 \mu \mathrm{Ci}\left[{ }^{3} \mathrm{H}\right]$ thymidine $(10$ $\mathrm{Ci} / \mathrm{mmol}$ ), $200 \mathrm{ng} / \mathrm{ml}$ PDGF, 5\% Sm-C-deficient PPP, and increasing concentrations of $\mathrm{Sm} 1.2(A)$. Additional cultures were exposed to $5 \%$ Sm-C-deficient PPP plus a $1 / 5,000$ dilution of Sm 1.2 and increasing concentrations of PDGF $(B)$. The incorporation of $\left[{ }^{3} \mathrm{H}\right]$ thymidine into DNA was determined after a $30-\mathrm{h}$ incubation as in Fig. 1. The results are expressed as the mean $\pm 1 \mathrm{SD}$ for triplicate cultures. $(A)$ PDGF $(200 \mathrm{ng} / \mathrm{ml})$ plus $5 \% \mathrm{Sm}-\mathrm{C}-$ deficient PPP; $(B) 5 \% \mathrm{Sm}-\mathrm{C}-$ deficient PPP plus antibody $1 / 5,000$.
In other studies we have found that cultures that are transiently exposed to PDGF for $5 \mathrm{~h}$ and then placed in $2 \%$ Sm-C-deficient PPP secrete less Sm-C-like peptide than when PDGF and Sm-C-deficient PPP are present together throughout the study (20). In the present study, when a $1 / 2,000$ dilution of antibody was added to $2 \%$ Sm-C-deficient PPP after PDGF had been removed, there was only minimal suppression of $\left[{ }^{3} \mathrm{H}\right]$ thymidine incorporation that was not statistically significant (Fig. 3, left). Increasing concentrations of exogenously added pure $\mathrm{Sm}-\mathrm{C}$ induced significant increases in $\left[{ }^{3} \mathrm{H}\right]$ thymidine incorporation $(10,300 \pm 900-30,200 \pm 1,100 \mathrm{cpm})(P<0.01)$ in the absence of antibody, but in its presence Sm-C caused only a partial reversal of this effect $(9,800 \pm 1,000-17,200 \pm 1,100$ cpm) $(P<0.01)$ (Fig. 3, left). To control for the possibility of a nonspecific cytotoxic effect by the antibody preparation, identical cultures were exposed to PDGF followed by $2 \% \mathrm{Sm}$ C-deficient PPP plus increasing concentrations of porcine insulin (a known smooth muscle cell mitogen) (21). Addition of $10 \mu \mathrm{g} / \mathrm{ml}$ insulin in the presence of the antibody $(1 / 2,000$ dilution) stimulated $\left[{ }^{3} \mathrm{H}\right]$ thymidine incorporation to levels that were equal to control cultures that did not receive antibody (Fig. 3, right). To further control for the possible effects of the monoclonal antibody unrelated to $\mathrm{Sm}-\mathrm{C}$ binding, an additional monoclonal antibody to horse apoferritin that had been purified by the same method was incubated with the smooth muscle cell cultures. When dilutions between $1 / 10,000$ and $1 / 1,000$ of the antibody were used it had no inhibitory effect on cultures that were simultaneously exposed to $200 \mathrm{ng} / \mathrm{ml}$ PDGF and $2 \%$ Sm-C-deficient PPP.

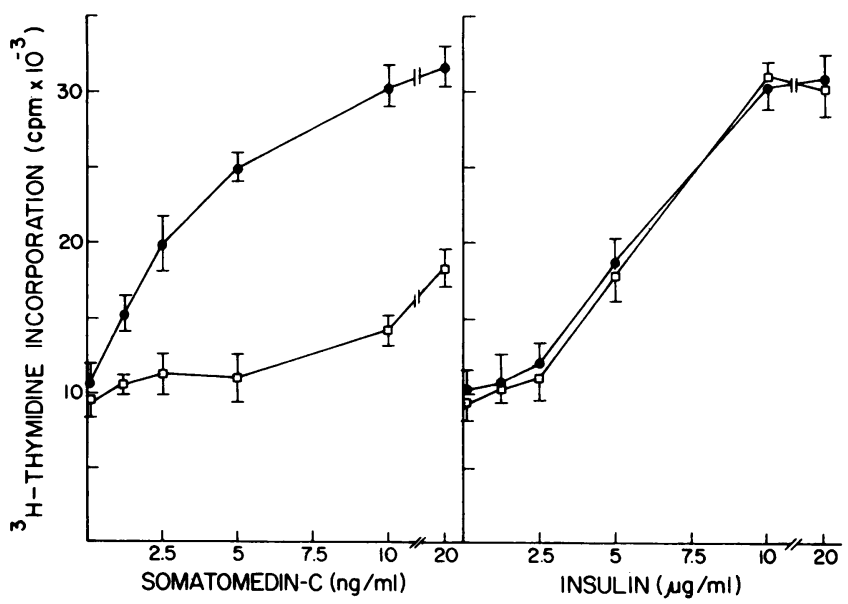

Figure 3. Effect of anti-Sm-C antibody on $\mathrm{Sm}-\mathrm{C}$ and insulin stimulation of DNA synthesis in smooth muscle cells. Cells were subcultured and grown to high density as described in Fig. $2.5 \mathrm{~d}$ after the last media change the media were aspirated, the cultures washed two times with serum-free DMEM, and exposed to $0.2 \mathrm{ml}$ serum-free DMEM that contained PDGF $(50 \mathrm{ng} / \mathrm{ml})$. After $3 \mathrm{~h}$, this reagent was aspirated, each well washed two times, and exposed to $0.2 \mathrm{ml}$ DMEM that contained $2 \% \mathrm{Sm}-\mathrm{C}$-deficient PPP and $0.5 \mu \mathrm{Ci}$ $\left[{ }^{3} \mathrm{H}\right]$ thymidine with (口) or without (๑) monoclonal anti-Sm-C antibody $1 / 2,000$. Triplicate cultures received various concentrations of $\mathrm{Sm}-\mathrm{C}($ left $)$ or insulin (right). After a 30-h incubation, the reaction was terminated by the addition of $50 \mu \mathrm{l}$ of $1.0 \mathrm{M}$ ascorbic acid and $\left[{ }^{3} \mathrm{H}\right]$ thymidine incorporation determined as in Fig. 1 . The results are expressed as the mean \pm 1 SD for triplicate cultures. $\square$, PDGF then Sm-C-deficient PPP plus Ab 1/2,000; •, PDGF then Sm-Cdeficient PPP. 
To determine if secretion of the Sm-like peptide by cultured smooth muscle cells is linked to cell replication as well as DNA synthesis, smooth muscle cell cultures were exposed to $200 \mathrm{ng} / \mathrm{ml}$ PDGF plus 5\% Sm-C-deficient PPP and Sm 1.2. Cell number increased rapidly in the cultures that were not exposed to antibody (Table I); however, those that received either a $1 / 5,000$ or $1 / 1,000$ dilution had significant inhibition of cell proliferation.

\section{Discussion}

Somatomedin-C is a potent peptide growth factor that stimulates DNA synthesis in multiple cell types. Extracts of many tissues contain Sm-like peptides, and these substances are secreted into medium by fetal explants and many different types of cultured cells $(5,6,7,22)$. It has not been clear, however, if the production of these peptides represents an epiphenomenon that reflects growth or whether secretion of these peptides is causally linked to stimulation of replication. These studies demonstrate definitively that addition of a specific monoclonal anti-Sm-C antibody to cultured smooth muscle cells and fibroblasts results in significant inhibition of $\left[{ }^{3} \mathrm{H}\right]$ thymidine incorporation into these cell types. This effect is not due to nonspecific cytotoxicity, since addition of insulin to cultures containing antibody allows full stimulation of $\left[{ }^{3} \mathrm{H}\right]$ thymidine incorporation. In addition, the effect of the antibody did not appear to be due to a change in the specific activity of the intracellular thymidine pool, since the addition of excess unlabeled thymidine in concentrations that are sufficient to correct differences in intracellular thymidine pools in many cell types did not result in a change in the response to antibody $(22,23)$.

Our previous observations, that growth-promoting peptides such as PDGF can stimulate the production of immunoreactive Sm-like substances by cultured human fibroblasts and porcine aortic smooth muscle cells, are now given greater relevance by our present finding that the secretion and release of these peptides into the medium plays an important role in the response of these cells to another mitogen. The observation that the antibody partially inhibited the effect of PDGF in both smooth muscle cells and fibroblasts suggests that PDGFinduced stimulation of DNA synthesis in these two cell types is due in part to stimulation of secretion of the Sm-like peptide. The residual stimulatory effect of PDGF in the presence of maximal inhibitory concentrations was probably due to stim-

Table I. Effect of Anti-Sm-C Antibody on Smooth Muscle Cell Growth

\begin{tabular}{ll}
\hline Test substance & $\begin{array}{l}\text { Cell number } \pm 1 \text { SD } \\
\text { (day 9) }\end{array}$ \\
\hline $5 \%$ Sm-C-deficient PPP & $8,537 \pm 774$ \\
PDGF $(200 \mathrm{ng} / \mathrm{ml})$ plus 5\% Sm-C-deficient & \\
$\quad$ PPP & $88,625 \pm 4,190^{*}$ \\
PDGF $(200 \mathrm{ng} / \mathrm{ml})$ plus Ab $1 / 5,000$ & $36,330 \pm 2,251 \ddagger$ \\
PDGF $(200 \mathrm{ng} / \mathrm{ml})$ plus Ab $1 / 1,000$ & $20,878 \pm 3,190 \ddagger$
\end{tabular}

${ }^{*} P<0.001$, compared with 5\% Sm-C-deficient PPP.

$\ddagger P<0.001$, compared with PDGF plus 5\% Sm-C-deficient PPP. ulation of cellular reactions that are independent of the Smlike peptide. The use of this antibody in future studies will permit quantitation of those growth factor-induced cellular reactions that are not dependent upon exposure to $\mathrm{Sm}$-C-like factors.

Several additional lines of evidence support the conclusion that production of $\mathrm{Sm}$-like peptides by cultured fibroblasts and smooth muscle cells helps to control their rates of replication. Secretion of the peptide is regulated by nonhormonal factors that regulate growth such as cell density, cell cycle timing, days since the last media change, and other hormones, such as growth hormone, fibroblast growth factor, insulin, and unknown factors in plasma (16). In addition, a highly purified preparation of the Sm-like peptide that is secreted by cultured fibroblasts stimulates human fibroblast replication. Taken together with the observation that the stimulatory effect of the partially purified preparation of fibroblast Sm can be blocked by addition of the monoclonal anti-Sm-C antibody, it appears that secretion of this peptide represents an important mechanism by which growth of this cell type is regulated.

Partial reversal of the antibody effect by the addition of $\mathrm{Sm}-\mathrm{C}$ or fibroblast $\mathrm{Sm}$ indicates that the antibody is not reducing $\left[{ }^{3} \mathrm{H}\right]$ thymidine incorporation by a mechanism independent of Sm-C. Using a 1/2,000 dilution of antibody in an incubation volume of $0.2 \mathrm{ml}$, the approximate calculated concentrations of free Sm-C would be 0.3 and $11 \mathrm{ng} / \mathrm{ml}$ (fibroblasts) and between 0.5 and $18 \mathrm{ng} / \mathrm{ml}$ (smooth muscle). These concentrations apparently were sufficient to stimulate DNA synthesis even in the presence of antibody. Fibroblast Sm appeared to be even more effective; however, caution should be used in interpreting this result, since both the exact chemical composition of the somatomedin species secreted by fibroblasts and smooth muscle cells and the absolute affinity of the antibody for these peptides are unknown.

Fibroblast Sm appears to be chemically distinct from SmC, since it has an apparent molecular weight of 20,500 and a neutral isoelectric point (18). Furthermore, by our best estimate, the affinity of the monoclonal antibody for fibroblast $\mathrm{Sm}$ is less than affinity for Sm-C, and this difference could account for the observed differences in the biologic response to these two peptides noted in Fig. 1. Presumably the antibody would bind less fibroblast $\mathrm{Sm}$, and therefore it would have a greater biopotency. These differences between the fibroblast Sm-like peptide and $\mathrm{Sm}-\mathrm{C}$ support the hypothesis that the cellular secretory product is a related but chemically distinct form of somatomedin, but do not exclude the possibility that it is a precursor of Sm-C.

Recently it has been possible to determine the partial nucleotide sequence of the Sm-C mRNA using human fetal $(24,25)$ and adult liver as tissue sources. Sequences coding for precursor peptides estimated to be in the $16,000 \mathrm{~mol} \mathrm{wt}$ range were identified as the major gene products. Since these larger molecular weight forms have been shown to exist, it is possible that the fibroblast secretory product represents a precursor form, or that it is a different gene product but has sufficient structural homology to cross-react with anti-Sm-C antibody. The latter possibility may be significant, since it appears that some growth regulatory peptides secreted by cells are related to cellular oncogene products (26). It is possible that production of Sm-like peptides by cultured cell types represents such a phenomenon, and raises further questions as to their role in the local control of growth of many types of cells and tissues. 


\section{Acknowledgments}

The authors gratefully acknowledge the secretarial assistance of Ms Geri Cox in preparing this manuscript. They acknowledge the technical assistance of Dave Zimmerman.

This work was supported by grants from the National Institutes of Health (5 RO1 AM 01022-29, to Dr. Van Wyk), HL 26309, AG02331 to Dr. Clemmons, and Career Research Award 5 KO6AM14115 to Dr. Van Wyk.

\section{References}

1. Van Wyk, J. J., and L. E. Underwood. 1978. The somatomedins and their actions. In Biochemical Action of Hormones. G. Litwak, editor. Academic Press, Inc., New York. 5:101-148.

2. Schoenle, E., J. Zapf, R. E. Humbel, and E. R. Froesch. 1982. Insulin-like growth factor I stimulates growth in hypophysectomized rats. Nature (Lond.). 296:252-253.

3. Heinreich, U. E., D. S. Schalch, J. G. Koch, and C. J. Johnson. 1978. Nonsuppressible insulin like activity (NSILA) II Regulation of serum concentrations by growth hormone and insulin. J. Clin. Endocrinol. Metab. 46:672-678.

4. Copeland, K. C., L. E. Underwood, and J. J. Van Wyk. 1980 Induction of immunoreactive somatomedin-C in human serum by growth hormone: dose response relationships and effect on chromatographic profiles. J. Clin. Endocrinol. Metab. 50:690-697.

5. D'Ercole, A. J., G. T. Applewhite, and L. E. Underwood. 1980. Evidence that somatomedin is synthesized by multiple tissues in the fetus. Dev. Biol. 75:315-378.

6. Atkison, P. R., E. R. Weidman, B. Bhaumick, and R. M. Bala. 1980. Release of somatomedin-like activity by cultured W138 human fibroblasts. Endocrinology. 106:2006-2012.

7. Clemmons, D. R., L. E. Underwood, and J. J. Van Wyk. 1981. Hormonal control of immunoreactive somatomedin production by cultured human fibroblasts. J. Clin. Invest. 67:10-17.

8. Atkison, P. R., and R. M. Bala. 1981. Partial characterization of a mitogenic factor with somatomedin-like activity produced by cultured WI38 human fibroblasts. J. Cell. Physiol. 107:317-323.

9. Clemmons, D. R., and J. J. Van Wyk. 1981. Somatomedin and platelet derived growth factor stimulate human fibroblast replication. J. Cell. Physiol. 106:361-367.

10. Baxter, R. C., S. Axiak, and J. Raison. 1982. Monoclonal antibody against somatomedin-C/insulin-like growth factor I. J. Clin. Endocrinol. Metab. 54:474-476.

11. Lauble, U. K., W. Beier, H. Binz, M. R. Ceilo, and R. E. Humble. 1982. Monoclonal antibodies directed to human insulin-like growth factor I (IGF-I). Use for radioimmunoassay and immunopurification of IGF. FEBS (Fed. Eur. Biochem. Soc.) Lett. 149:109-112.

12. Van Wyk, J. J., W. E. Russell, L. E. Underwood, M. E. Svoboda, G. Y. Gillespie, W. J. Pledger, E. Y. Adashi, and S. D. Balk. 1984. Action of somatomedins on cell growth: effect of selective neutralization of somatomedin-C (insulin-like growth factor I) with a monoclonal antibody. In Human Growth Hormone. S. Raiti, editor. Plenum Publishing Co., New York. In press.

13. Russell, W. E., J. J. Van Wyk, and W. J. Pledger. 1984. Inhibition of the mitogenic effects of plasma by a monoclonal antibody to somatomedin-C. Proc. Natl. Acad. Sci. USA. 81:2389-2394.

14. Ross, R. 1971. Smooth muscle cell II: growth of smooth muscle in culture and formation of elastic fibers. J. Cell. Biol. 50:172-178.

15. Clemmons, D. R., W. L. Isley, and M. T. Brown. 1983. Dialyzable factor in human serum of platelet origin stimulates endothelial cell replication and growth. Proc. Natl. Acad. Sci. USA. 80: 1641-1646.

16. Clemmons, D. R., and D. S. Shaw. 1983. Variables controlling somatomedin production by cultured human fibroblasts. J. Cell. Physiol. 115:137-143.

17. Bradford, M. 1976. A rapid and sensitive method for the quantitation of microgram quantities of protein utilizing the principle of protein-dye binding. Anal. Biochem. 72:248-254.

18. Svoboda, M. E., J. J. Van Wyk, D. G. Klapper, R. E. Fellows, F. R. Grissom, and R. J. Schleuter. 1980. Purification of somatomedin$\mathrm{C}$ from human plasma: chemistry and biologic properties, partial sequence analysis and relationship to other somatomedins. Biochemistry. 19:790-797.

19. Clemmons, D. R., and D. S. Shaw. Purification and biologic properties of fibroblast somatomedin. J. Biol. Chem. In press.

20. Stout, R. W., E. L. Beirman, and R. Ross. 1975. Effect of insulin on the proliferation of cultured private arterial smooth muscle cells. Circ. Res. 36:319-327.

21. D'Ercole, A. J., A. D. Stiles, and L. E. Underwood. 1984. Tissue concentrations of somatomedin-C further evidence for multiple tissues of synthesis and paracrine or autocrine mechanisms of action. Proc. Natl. Acad. Sci. USA. 81:935-939.

22. Cleaver, J. E. 1967. Thymidine metabolism: the four factor model of pool sizes and growth inhibition. In Thymidine Metabolism and Cell Kinetics. North Holland Publishing Co., Amsterdam. 70104.

23. Adams, R. L. P. 1969. The effect of endogenous pools of thymidylate on the apparent rate of DNA synthesis. Exp. Cell Res. 56:55-59.

24. Jansen, M., M. A. Van Schait, A. T. Ricker, B. Bullock, D. E. Woods, K. H. Gabbay, A. L. Nussbaum, J. S. Sussenbach, and J. L. Van den Brande. 1983. Sequence of DNA encoding human insulinlike growth factor I precursor. Nature (Lond.). 306:609-611.

25. Ulrich, A., C. H. Berman, T. J. Pul, A. Gray, and J. M. Lee. 1984. Isolation of the human insulin-like growth factor I gene using a single synthetic DNA probe. EMBO (Eur. Mol. Biol. Organ.) J. 3: 361-364.

26. Duell, T. F., I. S. Huang, S. S. Huang, P. Stroobant, and M. D. Waterfield. 1983. Expression of a platelet-derived growth factorlike protein in simian sarcoma virus transformed cells. Science (Wash. DC). 221:1348-1350. 